\title{
Journalistic Mass Media Management
}

\author{
M. Yoserizal Saragih \\ Universitas Islam Negeri Sumatera Utara, Indonesia \\ yosesaragih77@gmail.com
}

\section{Abstract}

This study aims to discuss the Journalistic Mass Media Management. This study use quantitative method. The result shows that Mass media consists of printed mass media and electronic mass media. Print mass media in the form of newspapers, magazines, books, tabloids, and so on. Meanwhile, electronic mass media can be in the form of television, internet and radio. The mass media also has several functions, including an information function, an agenda function, a liaison function for people, an education function, a persuasion function, and an entertaining function. The messages conveyed by the mass media are new, interesting, and important. The effects of the mass media are also very large for society. Self-change in society occurs because of the mass media. The effect of the mass media is also related to the message itself. Today, we know the development of the mass media is very fast. However, it would be nice if the mass media developed to carry messages in accordance with the culture of the Indonesian people. The mass media should provide useful messages for the wider community.
Keywords

journalistic, mass media;

management

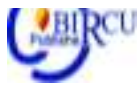

\section{Introduction}

Mass media consists of printed mass media and electronic mass media. Print mass media in the form of newspapers, magazines, books, tabloids, and so on. Meanwhile, electronic mass media can be in the form of television, internet and radio. The mass media also has several functions, including an information function, an agenda function, a liaison function for people, an education function, a persuasion function, and an entertaining function. The messages conveyed by the mass media are new, interesting, and important. The effects of the mass media are also very large for society. Self-change in society occurs because of the mass media. The effect of the mass media is also related to the message itself.

The information management activities are basically to produce printed materials (publications), broadcasts (radio, Tv), optical media films / videos, and even counseling. Every activist in distributing messages or information is a communication activity. In order to achieve a level of success in communication activities which include search, collection, and processing activities, as well as information distribution, management always requires management. Journalism in its sense, comes from the word "jour" (French) which means "diary". Since ancient Roman times, Julius Caesar, has known the word "Acta Diurma". Which means all activities from day to day (government announcements, etc.). The term journalism at this time, may already be familiar to the ear. In this current era, various information and telecommunication media greatly influence people's attitudes and behavior, especially in urban areas, even the mass media can influence people to remote rural areas.(Saragih, 2020) 
Journalism is a typical type of communication activity that focuses more on how to find, collect, select, and process information that contains news value, and present it to audiences through periodic mass media, both printed and electronic. Searching, collecting, selecting, and processing information containing news value into journalistic works and presenting them to audiences through mass media, require special expertise, foresight and skills, namely journalistic skills.

\section{Review of Literature}

\subsection{Mass Media}

Mass media is one of the tools in the mass communication process, because mass media is able to reach a wider and relatively larger audience, heterogeneous, anonymous, its messages are abstract and scattered. The mass media itself in the study of mass communication is often understood as instruments that are organized to communicate openly and in situations that are remote to a wide audience in a relatively short time.

According to Burhan Bungin in his book, mass media is a medium of communication and information that disseminates mass information and can be accessed by the public on a mass basis.

Saragih in Marzuki (2020) state that mass media is a tool used in conveying the message from the source to the audience by using mechanical means of communication, such as newspapers, radio, television and etc. In this case, here the mass media is print media or newspapers.

Mass media is a means of transmitting information, such as newspapers, magazines, books, films, radio and television, or a combination of shapes of media forms. Meanwhile, according to Cangara (2002: 134), mass media is a tool used in the delivery of a message from the source to the audience (receiver) using a mechanical of communication such as newspapers, radio, film and television. (Saragih, 2018)

Another case with Onong Effendy who said that the mass media was originally known as the term press which comes from the Dutch language, which in English means press. Press literally means print, and literally means broadcast broadcasting in print or print publication (printpublications). In its development the press has two definitions, namely the press in a narrow sense and the press in a broad sense. Press in a broad sense includes all publications, including electronic mass media, broadcast radio and broadcast television, while the press in a narrow sense is limited to printed mass media, namely newspapers, magazines and news agency bulletin.

\subsection{Types of Mass Media}

The term "mass media", which stands for "mass communication media", is used to denote the application of a technical device (media) that transmits or constitutes a medium for mass communication. From that point of view, we can say that mass media consists of:

1. Printed or printed media, namely newspapers, magazines, books, pamphlets, can even be expanded with billboards, and many other technical tools that can bring messages to many people.

2. Electronic media, namely broadcast radio or program in the sense of being auditive in nature; broadcast television or programs; a live film or picture in the sense that it is audiovisual, can be heard or seen.

Meanwhile, according to id.wikipedia.org, the types of mass media consist of:

1. Traditional mass media is a mass media with authority and has a clear organization as mass media. Traditionally the mass media are classified as follows: newspapers, 
magazines, radio, television, films (big screen). In this type of media there are characteristics such as:

- Information from the environment is selected, translated, and distributed.

- The mass media mediates and sends the information through certain channels.

- The recipient of the message is not passive and is part of the community and selects the information they receive.

- The interaction between source and receiver is minimal.

2. Modern mass media. Over time and the development of technology and socio-culture, other media have developed which are then grouped into mass media such as the internet and cellular phones. In this type of media there are characteristics such as:

- A source can transmit its message to multiple recipients (via SMS or the Internet for example).

- Message content is not only provided by institutions or organizations but also by individuals.

- There is no intermediary, the interaction occurs between individuals.

- Communication flows (takes place) inward.

- The recipient determines the interaction time.

\subsection{Mass Media Functions}

The mass media has encouraged a number of functions that were previously performed by other social institutions. Some of the functions of the mass media include:

1. Information Functions

The media has become a tool to find information for the public. From local, national and international news media can be accepted.

2. Agenda Function

Through the media, the human work agenda is determined. What people will do today are influenced by the media. Many people have the habit of "eating breakfast" by reading the newspaper or watching news on TV. Children choose to read comics based on films shown on TV.

3. People Liaison Function

It is undeniable that media has a function to connect humans to one another. Not only in terms of news, but also other information contained in newspapers will contain people in other areas.

4. Educational Function

The mass media more or less give messages about education. For example, how to maintain health, how to use suffrage, and so on.

5. Coax Function

After all, the media also has the power to persuade or seduce listeners, viewers or readers. The function of persuading is very thick when we see the advertising broadcasts in the mass media.

6. Entertaining function

This function is very thick in broadcast media, with many soap operas, music, comedy, and sports programs.

\subsection{Mass Mediaa Messages}

The mass media is basically just a tool or means of mass communication. Thus the mass media is tasked with delivering messages in mass communication. The message that is delivered must have certain elements in order to be well received by the masses. These elements are: 


\section{New}

This differentiates mass media from other social media, for example scientific forums, political meetings or religious lectures. The message conveyed is a new message.

Media that contain new information will be more attractive to the masses than media that carry old information. The mass media which contains today's news will be chosen by the masses over yesterday's news. The mass media that plays the latest film will be watched more by the masses than the mass media that plays the film (with the same quality as the latest film) produced last year.

\section{Interesting}

The mass media will contain messages or information that the public considers interesting. The meaning of interesting here has a broad meaning. Attractive can be in the physical sense, beautiful, nice, or beautiful.

Interesting can also be in the sense that in the message there are aspects that attract the public, including conflicts, violence, human interest, sex, and so on. Negative information is more attractive than positive messages

\section{Important}

Apart from new and interesting factors, the mass media also cannot leave the substance of the message element, namely the "important" factor. The mass media will publish message content that is considered important to the public, for example political policy issues that have a wide impact on society, natural disasters that concern the safety of many people, economies that concern the fate of the people, and so on.

\section{Discussion}

Mass communication is a communication process in which communication involves the wider community and is heterogeneous. Mass communication characteristics:

1. Using mass media with a clear organization (media agency).

2. One-way and general order, as well as through the production process and planned

3. Mass media activities are regular and continuous

4. There is the desired effect

5. In the social context there is mutual influence between the media and the conditions of society and vice versa.

6. The relationship between the communicator (usually the mass media) and the communicant (the audience) is not personal.

While the mass media is a channel or tool in mass communication. Mass media consists of printed mass media and electronic mass media. The printed mass media can be in the form of magazines, newspapers, books, and so on. Meanwhile, electronic mass media in the form of radio, television, and so on. Mass media (mass media) consists of two words, namely "media" and "mass". The mass media is an institution that is associated with many people or a neutral institution for all circles or society at large.

Marhaeni Fajar said: "The mass media as a channel for mass communication is an institution, namely an institution or organization, therefore, the communicator is institutionalized (institutionalizedcommunicator or organizedcommunicatior).

1. Using mass media with a clear organization (media agency).

2. One-way and general order, as well as through the production process and planned

3. Mass media activities are regular and continuous

4. There is the desired effect

5. In the social context there is mutual influence between the media and the conditions of society and vice versa. 
6. The relationship between the communicator (usually the mass media) and the communicant (the audience) is not personal.

While the mass media is a channel or tool in mass communication. Mass media consists of printed mass media and electronic mass media. The printed mass media can be in the form of magazines, newspapers, books, and so on. Meanwhile, electronic mass media in the form of radio, television, and so on.

Mass media (mass media) consists of two words, namely "media" and "mass". The mass media is an institution that deals with the public or a neutral institution for all circles or society at large.

Marhaeni Fajar said: "Mass media as a channel of mass communication is an institution, namely an institution or organization, therefore, the communicator is institutionalized (institutionalized communicator or organized communicator)."

Communication management is the study of how to manage information to achieve goals. The information management activities are basically to produce printed materials (publications), broadcasts (radio, tv), optical media films / videos, and even counseling. Every activist in distributing messages or information is a communication activity. In order to achieve a level of success in communication activities which include search, collection, and processing activities, as well as information distribution, management always requires management.

As has been explained that management is a process by utilizing the functions of planning, organizing, directing / implementing, and controlling to achieve organizational goals. Through these functions, messages or information are arranged and arranged in such a way as to suit various communication activities to achieve goals.

The range of communication activities can be divided into several types of activities, including: journalism, public relations, broadcasting, advertising and counseling. These activities require communication management in their management because in essence that the main essence of these activities is to provide information services to the public in accordance with the specific nature of these activities.

Journalism is a typical type of communication activity that focuses more on how to find, collect, select, and process information that contains news value, and present it to audiences through periodic mass media, both printed and electronic. According to Wahyudi (1996) searching, collecting, selecting, and processing information containing news values into journalistic works and presenting them to audiences through the mass media, requires expertise, carefulness, and separate skills, namely journalistic skills.

Journalistic skills include managerial skills in processing message content tailored to the specific characteristics of each media with the aim that the message content presented can be accepted by the audience (viewers, listeners, and readers) accurately and clearly so as not to cause other interpretations that can have an impact. widely among the community.

\section{Conclusion}

Mass media is a tool or channel of mass communication. Through the mass media, all messages will be conveyed to the public or the wider community. The mass media are indeed aimed at the "mass", namely the wider community. Mass media has a very important role for society. Mass media is able to provide the information needed by everyone, from children to adults. Through the mass media, human civilization is getting more advanced and far from backward.

Mass media consists of printed mass media and electronic mass media. Print mass media in the form of newspapers, magazines, books, tabloids, and so on. Meanwhile, 
electronic mass media can be in the form of television, internet and radio. The mass media also has several functions, including an information function, an agenda function, a liaison function for people, an education function, a persuasion function, and an entertaining function. The messages conveyed by the mass media are new, interesting, and important. The effects of the mass media are also very large for society. Self-change in society occurs because of the mass media. The effect of the mass media is also related to the message itself.

Today, we know the development of the mass media is very fast. However, it would be nice if the mass media developed to carry messages in accordance with the culture of the Indonesian people. The mass media should provide useful messages for the wider community.

The message conveyed should not be negative. Messages can be negative, as long as the meaning of the message is able to make the public aware of what should be improved.

\section{References}

Bungin, Burhan. (2006). Sosiologi Komunikasi. Jakarta: Kencana Prenada Media Group. Effendy, Onong Uchjana. (2002). Ilmu Komunikasi Teori dan Praktik. Bandung: PT Remaja Rosdakarya.

Fajar, Marhaeni. (2009). Ilmu Komunikasi Teori dan Praktik. Jakarta: Graha Ilmu.

Marzuki, D. et al. (2020). Identify the Principles of Perawi Hadith and Journalist Ethics. Budapest International Research and Critics Institute-Journal (BIRCI-Journal). P. 2039-2045

McQuall, Denis. (2000). Teori Komunikasi Massa. Jakarta: Erlangga.

Pratikto, Riyono. (1987). Berbagai Ilmu Komunikasi. Bandung: Remaja Karya CV.

Saragih,M. (2018). Some Characteristics of Islamic Journalism Based on Al Quran. Budapest International Research and Critics Institute-Journal (BIRCI-Journal). P. 0110

Saragih, M. and Harahap, A. (2020). The Challenges of Print Media Journalism in the Digital Era. Budapest International Research and Critics Institute-Journal (BIRCIJournal). P. 540-548

Suprapto, Tommy. (2009). Pengantar Teori Dan Manajemen Komunikasi, Yogyakarta: MedPress.

Susanto, Phil Astrid S. (1980). Komunikasi Sosial di Indonesia. Bandung: Bina Cipta.

Wardhani, Diah. (2008). Media Relation: Sarana Membangun Reproduksi Organisasi. Yogyakarta: Graha Ilmu.

Wiryawan, Hari. (2007). Dasar-Dasar Hukum Media. Yogyakarta: Pustaka Pelajar.

Fajar, Marhaeni. (2009). Ilmu Komunikasi Teori dan Praktik. Jakarta: Graha Ilmu. 